\title{
Breast Cancer pN2 TNM Finding v8
}

National Cancer Institute

\section{Source}

National Cancer Institute. Breast Cancer pN2 TNM Finding v8. NCI Thesaurus. Code C139438.

Breast cancer with metastases in 4-9 axillary lymph nodes; or positive ipsilateral internal mammary lymph nodes by imaging in the absence of axillary lymph node metastases. (from AJCC 8th Ed.) 